\title{
PERLINDUNGAN HUKUM BAGI ANAK YANG DIAMBIL PAKSA OLEH ORANG TUA YANG TIDAK MENDAPATKAN HAK ASUH ANAK
}

\author{
Fitria Dewi Navisa \\ Fakultas Hukum, Universitas Islam Malang, Indonesia. \\ Email :navisa@unisma.ac.id
}

\begin{abstract}
Abstrak
Perceraian merupakan pilihan terakhir untuk menentukan jalannya rumah tangga setiap pasangan. Dampak dari perceraian tidak selama membawa dampak negatif, tergantung dari alasan bercerai pada pasangan. Terutama dampak tersebut dapat menimbulkan anak menjadi terluka secara psikologis. Lalu timbul masalah mengenai hak asuh anak, dari hak asuh anak itulah sering terjadi perbeutan anak sehingga mengambil paksa anak di bawah kekuasaan orang tua yang tidak mendapatkan hak asuh. Tujuan penelitian ini adalah mengkaji bagaimana perlindungan hukum bagi anak yang diambil secara paksa oleh orang tua yang tidak mendapatkan hak asuh anak. Untuk menemukan jawaban atas permasalahan dalam penelitian ini, peneliti menggunakan teori-teori hukum tertentu yang digunakan sebagai landasan untuk menganalisanya. Teori tersebut meliputi ; Teori Perlindungan Hukum dan Teori Keadilan. Metode pendekatan yang digunakan ialah bersifat yuridis normatif. Penelitian ini menggunakan 2 macam pendekatan yakni Pendekatan Perundangundangan (Statute Approach) dan Pendekatan Konseptual (Conceptual Approach). Hak asuh anak diatur dalam Pasal 105 Kompilasi Hukum Islam yang menyatakan bahwa anak di bawah umur 12 tahun diasuh oleh ibunya, sedangkan anak di atas umur 12 tahun berhak memilih pemegang hak asuhnya di antara ayah atau ibunya. Biaya pemeliharaan ditanggung oleh ayahnya. Jika ayah tidak dapat memenuhi kewajiban tersebut, maka ibu dapat ikut andil dalam biaya tanggungan anaknya.
\end{abstract}

Kata Kunci : Perlindungan Hukum Anak; Orang Tua; Hak Asuh Anak.

\begin{abstract}
Abstact
Divorce is the last option for determining the course of each couple's household. The impact of divorce is not as long as it has a negative impact, depending on the reasons for divorce on the spouse. Especially these impacts can cause children to become hurt psychologically. Then the problem arises regarding child custody rights, from that child custody often occurs so that children forcibly take children under the control of parents who do not get custody. The purpose of this research is to examine how legal protection for children who are forcibly taken by parents who do not get child custody. To find answers to the problems in this study, researchers used certain legal theories which were used as a basis for analyzing them. The theory includes; Protection of Law Theory and Theory of Justice. The approach method used is normative juridical. This study uses 2 kinds of approaches, namely the statutory approach (statute approach) and the conceptual approach (conceptual approach). Custody of children is regulated in Article 105 of the Compilation of Islamic Law which states that children under 12 years of age are cared for by their mother, while children over 12 have the right to choose the holder of custody of their father or mother. Maintenance costs borne by his father. If the father is unable to fulfill this obligation, then the mother can share in the costs of the child's dependents.
\end{abstract}

Keywords: Child Legal Protection; Parents; Child custody. 


\section{A. PENDAHULUAN}

Anak merupakan suatu anugerah dari Tuhan YME bagi setiap orang tua. Tanggung jawab setiap orang tua juga diperlukan dalam hal mendidik anak. Setiap anak berhak memiliki kelangsungan hidup, tumbuh dan berkembang menjadi anak bangsa yang berprestasi dan berhak mendapatkan perlindungan di setiap hidupnya. Anak memiliki potensi di dalam dirinya dan akan menjadi generasi penerus bangsa yang berguna di masa depan. Hukum merupakan satu-satunya jaminan bagi perlindungan anak. Arif Gosita mengemukakan pendapat bahwa kepastian hukum perlindungan anak dan mencegah penyelewengan yang mengakibatkan dampat negatif dalam perlindungan anak ${ }^{1}$. Orang tua berhak memberikan hak dan kewajibannya kepada anak. Anak berhak mendapatkan perlindungan, pendidikan, kasih sayang, dan lain-lain yang diberikan oleh orang tuanya. Orang tua juga harus mengerti dan memahami batasanbatasan anak supaya anak tidak merasa tidak berguna. Setiap anak juga membutuhkan orang tua yang peduli akan kelangsungan hidupnya. Dari situ anak akan merasa terjaga dengan adanya orang tua.

Perceraian yang terjadi di setiap orang tua kerap menimbulkan kesan negatif terhadap orangorang sekitar. Suasana keluarga yang seperti ini cenderung membuat anak-anak tidak dapat melanjutkan pendidikannya dengan baik dan bahkan dapat membawa dampak negatif bagi psikologi anak. Menurut Zakiah Drajat, terdapat beberapa hal yang menjadi tanggungjawab orang tua terhadap anaknya :

1. Memperkenalkan nikmat dan karunia Tuhan YME

2. Membimbing anaknya dalam agama

3. Memberi nama bagi anak

4. Memperjelas keturunan

5. Selalu mendoakan kepada anaknya ${ }^{2}$.

Perlindungan anak dari perceraian, kekerasan dan diskrimasi sangat perlu diperhatikan. Kasus-kasus kekerasan dan diskriminasi terhadap anak seringkali terjadi. Anak yang menjadi korban tersebut dapat mengakibatkan trauma yang dalam. Setelah putusan perceraian dan hak asuh anak ditetapkan, banyak pihak ayah atau ibu tidak terima. Sehingga terjadi pengambilan anak secara paksa. Menurut Pasal 105 Kompilasi Hukum Islam, anak yang belum berusia 12 tahun adalah hak ibunya. Setelah anak berusia 12 tahun, maka ia akan diberikan kebebasan memilih untuk diasuh oleh ayah atau ibunya. Dan selama anak diasuh oleh ayah atau ibunya, biaya pengasuhan anak ditanggung oleh ayah ${ }^{3}$. Perlindungan anak yang dilakukan perlu memperhatikan dampak terhadap lingkungan dan anak itu sendiri. Perlindungan anak yang berlebihan juga tidak dapat dilakukan karena dapat mengganggu fisik, psikis, dan aktivitas sosialnya.

Perlindungan anak dijelaskan dalam Undang -Undang No. 23 Tahun 2002 tentang Perlindungan Anak. Dalam Pasal 1 Ayat 1 Undang-Undang No. 23 Tahun 2002 tentang Perlindungan Anak menyebutkan bahwa perlindungan anak adalah segala kegiatan untuk menjamin dan melindungi anak dan hak-hak nya agar tetap hidup, tumbuh, dan berkembang dan berpartisipasi secara optimal sesuai dengan harkat dan martabat kemanusiaan, serta mendapat perlindungan dari kekerasan dan diskriminasi. Pasal 45 Ayat (1) dan Ayat (2) Undang-Undang No. 1 Tahun 1974 tentang Perkawinan menjelaskan bahwa kewajiban kedua orang tua memelihara dan mendidik anak sebaik-baiknya sampai anak tersebut kawin atau dapat berdiri sendiri, kewajiban mana berlaku terus meskipun perkawinan antara kedua orang

\footnotetext{
${ }^{1}$ Arif Gosita. (1998). Masalah Perlindungan Anak. Jakarta: Akademika Pressindo. hlm. 34.

${ }^{2}$ Zakiah Drajat. (1979). Ilmu Jiwa Agama. Jakarta: Bulan Bintang. hlm. 36.

${ }^{3}$ Fitri N Hariani, 2018, Perkawinan Retak, Hak Asuh Anak Diperebutkan (diakses pada 12 April 2020 dari https://www. hukumonline.com/berita/baca/lt5b1 fa3dce96d9/perkawinan-retak--hak-asuh-anak-diperebutkan/)
} 
tua putus. Dalam hal ini, walaupun ikatan perkawinan kedua orang tua putus, orang tua berhak menjalankan kewajiban untuk menghidupi anaknya yang diasuh oleh ayah atau ibunya. Ketika ayah merasa tidak sanggup membiayai hidup anak, istri juga harus ikut andil membiayai hidup anak. Permasalah yang akan dikaji dalam penelitian ini adalah bagaimana bentuk perlindungan hukum bagi anak yang diambil paksa oleh orangtua yang tidak mendapatkan hak asuh anak.

Anak merupakan suatu anugerah yang diberikan kepada setiap pasangan dari Tuhan Yang Maha Esa untuk bertanggungjawab atas hidup anak tersebut. Ketika hak asuh anak jatuh di tangan yang salah dapat berakibat jangka panjang kepada anak tersebut. Terutama mengenai perkembangan psikologis anak yang akan terbawa sampai ia tumbuh dewasa nanti. Banyak orang tua yang tidak memiliki kedekatan secara psikologis dengan sang anak. Pengasuhan anak ditentukan oleh pengadilan. Saat pengadilan membahas mengenai pengasuhan anak jatuh ke tangan siapa, masih banyak pernyataan yang harus dipertimbangkan karena menyangkut masa depan anak akan diasuh dan dirawat oleh siapa. Apalagi ketika terjadi hal yang tidak diinginkan, misalnya seperti seorang ayah dan ibu bercerai, dan sang anak masih berumur di bawah 12 tahun. Kebanyakan hak asuh anak jatuh ke tangan ibunya ${ }^{4}$. Ketika sang anak sekolah, sang ayah menjemput anak tersebut dari sekolah dan membawanya pergi untuk jalan-jalan tanpa izin dari pemegang hak asuh anak, yaitu ibunya. Lalu sang ayah tidak mengembalikan sang anak kepada ibunya. Sehingga sang ayah dapat dituntut secara pidana karena telah mengambil seorang di bawah umur tanpa izin dari pemegang hak asuh anak 5

\section{B. METODE PENELITIAN}

Metode pendekatan yang digunakan adalah yuridis normatif. Penelitian hukum normatif dilakukan dengan cara menggunakan meneliti bahan pustaka atau data normatif dilakukan dengan cara menggunakan meneliti bahan pustaka atau data sekunder yang meliputi sumber hukum primer dan sumber hukum sekunder. Menurut Soerjono Soekanto pendekatan secara yuridis normatif adalah penelitian hukum yang dilakukan dengan cara meneliti bahan pustaka atau data sekunder sebagai bahan dasar untuk diteliti dengan cara mengadakan penelusuran terhadap peraturan-peraturan dan literature-literatur yang berkaitan dengan permasalahan yang diteliti ${ }^{6}$. Penelitian hukum normatif dilakukan dengan mengkaji undang-undang yang berkaitan dengan perlindungan anak, menemukan norma-norma yang berkaitan dengan perlindungan anak. Pendekatan yuridis normatif menerapkan undang-undang dan teori-teori hukum perlindungan anak. Menurut Johnny Ibrahim, penelitian hukum normatif adalah suatu prosedur penelitian ilmiah untuk menemukan kebenaran berdasarkan logika keilmuan dari sisi normatifnya ${ }^{7}$.

Penelitian ini menggunakan 2 macam pendekatan, yaitu pendekatan perundang-undangan (Statute Approach) dan pendekatan konseptual (Conceptual Approach). Penelitian hokum normatif sama sekali tidak menggunakan data. Penelitian ini berdasakan sumber hukum primer, yakni berdasarkan undang-undang. Bahan hukum yang digunakan dalam penelitian ini berasal dari kepustakaan. Oleh karena itu teknik pengumpulan bahan hukum yang digunakan dalam penelitian ini yaitu dengan pengumpulan data dari pustaka. Pengumpulan bahan hukum yang dilakukan dengan cara penelusuran yaitu (1) menelusuri norma-norma yang berkaitan dengan perlindungan anak, dan (2) menganalisis secara mendalam sehingga menjawab rumusan masalah.

\footnotetext{
${ }^{4}$ Lihat Pasal 105 Kompilasi Hukum Islam (KHI).

${ }^{5}$ Lihat Pasal 330 Kitab Undang-Undang Hukum Pidana (KUHP).

${ }^{6}$ Sorejono Soekanto \& Sri Mamudji. (2001). Penelitian Hukum Normatif (Suatu Tinjauan Singkat). Jakarta: Rajawali Pers. hlm 13-14.

${ }^{7}$ Johnny Ibrahi. (2013). Teori dan Metodologi Penelitian Hukum Normatif. Malang: Bayumedia. hlm. 57.
} 


\section{PEMBAHASAN}

Perkawinan berasal dari kata " kawin " yang menurut Bahasa berarti membentuk keluarga dengan lawan jenis, melakukan hubungan kelamin atau bersetubuh, dan juga berasal dari kata " an-nikah " yang menurut Bahasa berarti mengumpulkan, saling memasukkan, dan wathi atau bersetubuh ${ }^{8}$. Berdasarkan Pasal 1 Undang- Undang No. 1 Tahun 1974 tentang Perkawinan, perkawinan adalah ikatan lahir dan batin antara seorang pria dengan seorang wanita sebagai suami istri dengan tujuan membentuk keluarga (rumah tangga) yang bahagia dan kekal berdasarkan Ketuhanan Yang Maha Esa ${ }^{9}$. Ahmad Azhar Basyir mengungkapkan bahwa tujuan perkawinan dalam Islam adalah untuk memenuhi tuntutan naluri hidup manusia, berhubungan dengan laki-laki dan perempuan, dalam rangka mewujudkan kebahagiaan keluarga sesuai ajarannya Allah SWT dan Rasul-Nya ${ }^{10}$. Tujuan perkawinan tersebut tidak selamanya berjalan dengan lancar dan terwujud sesuai dengan harapan, dimana di dalam setiap rumah tangga juga terjadi pertengkaran yang memicu retaknya sebuah rumah tangga dan hubungan antara suami dan istri. Terlebih lagi jika istri melahirkan dan memiliki anak. Masih banyak yang perlu dipertimbangkan lagi untuk harapan dan masa depan anak. Semua berada di tangan para orang tua. Hak dan kewajiban kehidupan anak ditanggung oleh orang tua.

Menurut Subekti, perceraian adalah penghapusan perkawinan dengan putusan hakim, atau tuntutan salah satu pihak dalam perkawinan itu ${ }^{11}$. Menurut P. N. H. Simanjutak, perceraian ialah pengakhiran suatu perkawinan karena suatu sebab dengan keputusan hakim atas tuntutan dari salah satu pihak atau kedua belah pihak dalam perkawinan ${ }^{12}$. Perceraian termuat dalam Pasal 38 sampai Pasal 41 Undang-Undang No. 1 Tahun 1974 tentang Perkawinan. Tata cara perceraian dijelaskan pada Pasal 14 sampai Pasal 36 Peraturan Pemerintah Republik Indonesia No. 9 Tahun $1975^{13}$ sebagaimana disebutkan dalam Pasal 40 Ayat (2) Undang-Undang No. 1 Tahun 1974 tentang Perkawinan. Adapun yang menjadi alasan putusnya perkawinan yakni ${ }^{14}$ :

1) Karena kematian;

2) Karenakeadaan tak hadir si suami atau si istri selama sepuluh tahun, diikuti dengan perkawinan baru istrinya/suaminya sesuai dengan ketentuan-ketentuan dalam bagian ke lima bab delapan belas;

3) Karena putusan hakim setelahadanya perpisahan meja dan ranjang dan pembukuan pernyataan bubarnya perkawinan dalam putusan itu dalam register catatan sipil, sesuai dengan ketentuanketentuan bagian ke dua bab ini;

4) Karena perceraian sesuai dengan ketentuan-ketentuan dalam bagian ke tiga bab ini.

Perceraian merupakan suatu bencana dalam suatu rumah tangga. Dampak yang diberikan setelah perceraian tidak seterusnya berdampak negaitf, tergantung dengan apa yang menjadi alasan perceraian itu. Dampak dari perceraian dapat berimbas kepada anak, tergantung bagaimana anak ketika menyikapi keputusan orang tua mereka untuk bercerai. Perceraian atau perpisahan dapat terjadi karena alasan ${ }^{15}$ :

a. Salah satu pihak berbuat zina atau menjadi pemabok, pemadat, penjudi, dan lain sebagainya yang sukar disembuhkan;

\footnotetext{
${ }^{8}$ Abdul Rahman Ghozali. (2003). Fiqh Munakahat. Jakarta: Prenada Media Group. Hlm. 8.

${ }^{9}$ Lihat Pasal 1 Undang-Undang Republik Indonesia Nomor 1 Tahun 1974 tentang Perkawinan.

${ }^{10}$ Ahmad Azhar Basyir. (2000). Hukum Perkawinan Islam. Yogyakarta: UI Pres. hlm. 86.

${ }^{11}$ Subekti. (1985). Pokok-Pokok Hukum Perdata. Jakarata: Intermasa, hlm. 23.

${ }^{12}$ P. N. H. Simanjutak. (2007). Pokok-Pokok Hukum Perdata Indonesia. Jakarta: Pusaka Djambatan. hlm. 53.

${ }^{13}$ Lihat Pasal $14 \mathrm{~s} / \mathrm{d} 36$ Peraturan Pemerintah Republik Indonesia No. 9 Tahun 1975 tentang Pelaksanaan Undang-Undang No. 1 Tahun 1974 Tentang Perkawinan.

${ }^{14}$ Lihat Pasal 40 Undang-Undang No. 1 Tahun 1974 tentang Perkawinan.

${ }^{15}$ Lihat Pasal 19 Peraturan Pemerintah No. 9 Tahun 1975 tentang Pelaksanaan Undang-Undang No. 1 Tahun 1974 tentang Perkawinan.
} 
b. Salah satu pihak meninggalkan pihak selama 2 (dua) tahun berturut-turut tanpa izin pihak lain dan tanpa alasan yang sah atau karena hal lain di luar kemampuannya;

c. Salah satu pihak mendapatkan hukuman penjara 5 (lima) tahun atau hukum yang lebih berat setelah perkawinan berlangsung;

d. Salah satu pihak melakukan kekejaman atau penganiayaan berat yang membahayakan pihak lain;

e. Salah satu pihak mendapatcacatbadanatau penyakitdengan akibattidak dapatmenjalankan kewajibannya sebagai suami/isteri;

f. Antara suami dan istreri terus menerus terjadi perselisihan dan pertengkaran dan tidak ada harapan akan hidup rukun lagi dalam rumah tangga.

Anak merupakan suatu anugerah dari Tuhan Yang Maha Esa yang diberikan kepada setiap orang tua. Hak dan kewajiban setiap orang tua adalah menjaga dan memenuhi kebutuhan hidupnya sampai ia menikah ${ }^{16}$. Setiap anak berhak mendapatkan rasa aman, hak untuk hidup, kebebasan, dan lain sebagainya ${ }^{17}$. Dalam diri setiap anak sudah memiliki hak dan kewajiban untuk dilindungi oleh undang-undang dan orang tua selaku subyek utama dalam rumah tangga. Ketika suatu rumah tangga retak lalu terjadi perceraian, perlindungan hukum bagi anak sudah mulai berlaku. Dampak dari perceraian kepada anak sangatlah besar dan mungkin dapat terbawa sampai ia dewasa. Permasalahan utama dalam perceraian ialah hak asuh anak. Hal ini sering memicu suatu permasalahan diantara dua pihak, yaitu ayah atau ibu yang telah resmi bercerai bahkan sebelum perceraian terjadi. Orang tua sering memperebutkan hak asuh anaknya, dan pengambilan anak secara paksa pun terjadi. Hukum perlindungan anak pun disini sudah berlaku. Pengertian pengasuhan anak dijelaskan dalam Peraturan Menteri Sosial No. 21 Tahun 2013 tentang Pengasuhan Anak ${ }^{18}$ yakni "Pengasuhan anak adalah upaya untuk memenuhi kebutuhan akan kasih sayang, kelekatan, keselamatan, dan kesejahteraan yang menetap dan berkelanjutan demi kepentingan terbaik anak yang dilaksanakan baik oleh orang tua atau keluarga sampai derajat ketiga maupun orang tua asuh, orang tua angkat, wali serta pengasuhan berbasis residensial sebagai alternatif terakhir". Dalam undang-undang sudah dijelaskan bahwa setiap anak berhak diasuh, dibesarkan oleh orang tua sendiri ${ }^{19}$. Hal ini menjelaskan bahwa anak harus mengetahui keadaan orang tuanya, bercerai atau tidak. Dan selama menjadi orang tua wajib menjalankan kewajibannya sebagai orang tua dan memberikan hak-hak nya kepada anak. Pasal 105 Kompilasi Hukum Islam (KHI) menyebutkan bahwa ${ }^{20}$ :

Dalam hal terjadinya perceraian :

a. Pemeliharaan anak yang belum mumayyiz atau belum berumur 12 tahun adalah anak ibunya.

b. Pemeliharan anak yang sudah mumayyiz diserahkan kepada anak untuk memilih diantara ayah dan ibunya sebagai pemegang hak pemeliharaannya.

c. Biaya pemeliharaan ditanggung ayahnya."

Pasal di atas menjelaskan bahwa anak yang di bawah 12 tahun adalah hak ibu untuk menjaga dan merawat. Sedangkan anak yang sudah diatas 12 tahun memilih di antara ayah atau ibunya sebagai pemegang hak pemeliharaannya. Dan untuk biaya pemeliharaan anak ditanggung oleh ayahnya. Biaya pemeliharaan yang ditujukan kepada anak juga ditegaskan dalam Pasal 41 huruf a dan b Undang-Undang No. 1 Tahun 1974 tentang Perkawinan ${ }^{21}$. Pasal 41 UndangUndang No. 1 Tahun 1974 Tentang Perkawinan menyatakan bahwa:

${ }^{16}$ Lihat Pasal 45 s/d 49 Undang-Undang No. 1 Tahun 1974 tentang Perkawinan.

${ }^{17}$ Lihat Pasal 4 Undang-Undang No. 23 Tahun 2002 tentang Perlindungan Anak.

${ }^{18}$ Lihat Ketentuan Umum dalam Peraturan Menteri Sosial Republik Indonesia No. 21 Tahun 2013 tentang Pengasuhan Anak.

${ }^{19}$ Lihat Pasal 7 Ayat (1) Undang-Undang No. 23 Tahun 2002 tentang Perlindungan Anak.

${ }^{20}$ Lihat Pasal 105 Kompilasi Hukum Islam (KHI).

${ }^{21}$ Steven Lie, 2019, Cara Mengajukan Gugatan Nafkah Anak ke Pengadilan Negeri (diakses pada 20 April 2020 dari https:/www.hukumonline.com/klinik/detail/ulasan/lt5680f6d47502d/cara-mengajukan-gugatan-nafkah-anak-ke-penga- 
a. Baikibuatau bapak tetap berkewajibanmemelihara dan mendidikanak-anaknya, semata-mata berdasarkan kepentingan anak; bilamana ada perselisihan mengenai penguasaan anak-anak, Pengadilan memberikan keputusannya;

b. Bapakyangbertanggungjawabatas semuabiayapemeliharaandanpendidikanyangdiperlukan anakitu;bilamanabapakdalamkenyataantidakdapatmemenuhikewajibantersebut,Pengadilan dapat menentukan bahwa ibu ikut memikul biaya tersebut.

Dalam pasal diatas menjelaskan bahwa ayah atau ibu tetap berkewajiban memelihara dan mendidik anak-anak setelah bercerai, apabila terdapat perselisihan mengenai penguasaan anak, dapat diajukan ke Pengadilan. Ayah bertanggungjawab atas seluruh biaya pemeliharaan sang anak, termasuk pendidikan yang dibutuhkan. Apabila ayah tidak dapat memenuhi kewajiban tersebut, pengadilan dapat membuat keputusan bahwa ibu ikut andil dalam memikul biaya pemeliharaan tersebut. Perspektif orang yang tidak mendapatkan hak asuh maka maish berhak bertemu dengan anaknya, namun tidak bisa membawanya tanpa ijin walau hanya untuk sekedar pergi untuk mengunjungi suatu tempat. Mengenai bisa atau tidak membawa anak tanpa izin dari pemegang kuasa anak, terdapat ketentuan dalam Pasal 330 Kitab Undang-Undang Pidana (KUHP) yang menyatakan bahwa ${ }^{22}$ :

1) Barang siapa sengaja menarik seorang yang belum cukup umur dari kekuasaan yang menurut undang-undang ditentukan atas dirinya, atau dari pengawasan orang yang berwenang untuk itu, diancan dengan pidana penjara paling lama tujuh tahun.

2) Bilamana dalam hal ini dilakukan tipu muslihat, kekerasan atau ancaman kekerasan, atau bilamana anaknya belum cukup umur dua belas tahun, dijatuhkan pidana penjara paling lama sembilan tahun.

Dari pasal di atas dapat dijelaskan bahwa yang dapat diancam dengan pidana penjara ialah orang dengan sengaja menarik/mengambil orang yang belum dewasa (anak-anak) dari kekuasaan yang berhak, yaitu pemegang hak asuh anak dan diancam dengan pidana penjara paling lama 7 (tujuh) tahun. Dan apabila terdapat tipu muslihat, kekerasan atau ancaman kekerasan untuk menarik/mengambil anak belum berumur 12 (dua belas) tahun dari pemegang kuasa atas anak, diancam dengan pidana penjara paling lama 9 (sembilan) tahun.

R. Soesilo mengatakan bahwa dalam hal ini harus dapat dibuktikan bahwa jika memang pelaku yang menarik/mengambil anak tersebut, bukan keinginan anaknya sendiri yang melepaskan diri dari pemegang hak asuh anak. Menurut arrest Hoge Raad 2 November 1903, apabila anak yang belum dewasa melarikan diri/melepaskan diri atas dasar kemauan anak itu sendiri dari pemegang hak asuhnya dan meminta perlindungan kepada orang lain dan orang tersebut menolak untuk mengembalikan lagi anak tersebut kepada pemegang hak asuhnya, maka penolakan dari perlindungannya tidak dapat dikatakan perbuatan menarik seseorang yang belum cukup umur dari kekuasaan yang sudah ditentukan ${ }^{23}$. Dalam perundang-undangan batasan usia anak-anak juga diatur, tetapi belum menemukan kesamaan antara setiap perundangundangan. Ketidaksamaan inilah yang seringkali menimbulkan banyak pertanyaan. Berikut adalah beberapa pengaturan batasan usia anak berdasarkan peraturan perundang - undangan yang berlaku di Indonesia.

1. Pasal 45 Kitab Undang Undang Hukum Pidana (KUHP) ${ }^{24}$ :

"Dalam menurut orang yang belum cukup umur (minderjarig) karena melakukan perbuatan sebelum umur enam belas tahun... “

dilan-negeri/)

${ }^{22}$ Lihat Pasal 330 Kitab Undang-Undang Hukum Pidana (KUHP).

${ }^{23}$ Sovia Hasanah, 2019, Melaporkan Pidana Mertua yang Melarang Menemui Anak Sendiri (diakses pada 28 April 2020 dari https://www.hukumonline.com/klinik/detail/ulasan/lt5169407db97ce/melaporkan-pidana-mertua-yang-melarang-menemui-anak-sendiri/)

${ }^{24}$ Lihat Pasal 45 Kitab Undang-Undang Hukum Pidana

174 Fitria Dewi Navisa | Perlindungan Hukum Bagi Anak .... 
2. Pasal 47 Undang-Undang No. 1 Tahun 1974 tentang Perkawinan ${ }^{25}$

1) Anakyang belum mencapai umur 18 (delapan belas) tahun atau belum pernah melangsungkan perkawinan ada di bawah kekuasaan orang tuanya selama mereka tidak dicabut dari kekuasaannya.

2) Orang tua mewakili anak tersebut mengenai segala perbuatan hukum didalam dan diluar Pengadilan.

3. Pasal 1 Ayat (26) Undang-Undang No. 13 Tahun 2003 tentang Ketenagakerjaan ${ }^{26 .}$

"Anak adalah setiap orang yang berumur di bawah 18 (delapan belas) tahun."

4. Undang-Undang No. 11 Tahun 2012 tentang Sistem Peradilan Pidana Anak ${ }^{27}$

Pasal 1 Ayat (3): " Anak yang berkonflik dengan hukum yang selanjutnya disebut anak adalah anak yang telah berumur 12 (dua belas) tahun, tetapi belum berumur 18 (delapan belas ) tahun yang diduga melakukan tindak pidana.

Pasal 1 Ayat (4): “ Anakyang menjadi korban tindak pidana yang selanjutnya disebut anak korban adalah anak yang belum berumur 18 (delapan belas) tahun yang mengalami penderitaan fisik, mental, dan / atau kerugian ekonomi yang disebabkan oleh tindak pidana. “ Pasal 1 Ayat (5): “ anak yang menjadi saksi tindak pidana yang selanjutnya disebut anak saksi adalah anak yang belum berumur 18 (delapan belas) tahun yang dapat memberikan keterangan guna kepentingan penyidikan, penuntutan, dan pemeriksaan di sidang Pengadilan tentang suatu perkara yang didengar, dilihat, dan/atau dialaminya sendiri.

5. Pasal 1 Ayat (1) Undang-Undang No. 23 Tahun 2002 tentang Perlindungan Anak ${ }^{28}$ :

“ Anak adalah seseorang yang belum berusia 18 (delapan belas) tahun, termasuk anak yang masih dalam kandungan. "

Dari beberapa perundang-undangan di atas, dalam Pasal 330 Kitab Undang-Undang Hukum Pidana (KUHP), "seorang yang belum cukup umur" merujuk pada Pasal 1 Ayat (1) UndangUndang No. 23 tentang Perlindungan Anak, yakni untuk anak yang belum berusia 18 (delapan belas) tahun.

\section{KESIMPULAN}

Dalam Pasal 1 Undang-Undang No. 1 Tahun 1974 tentang Perkawinan, perkawinan ialah ikatan lahir batin antara seorang pria dengan seorang wanita sebagai suami isteri dengan tujuan membentuk keluarga (rumah tangga) yang bahagia dan kekal berdasarkan Ketuhanan Yang Maha Esa. Tujuan perkawinan adalah untuk membentuk sebuah keluarga yang bahagia dan kekal. Dalam setiap rumah tangga diharapkan dapat berjalan lancar sesuai dengan tujuan perkawinan. Terdapat juga berbagai permasalahan yang dapat memicu pertengkaran hingga berakibat perceraian. Apabila sudah memiliki anak, banyak yang perlu dipertimbangkan lagi untuk bercerai. Perceraian merupakan pilihan atau opsi terakhir dalam mengakhiri perkawinan. Perceraian juga dapat terjadi karena kurangnya komitmen pasangan dalam menjalani hidup rumah tangga, sehingga hal tersebut memicu pertengkaran pada pasangan dan memilih berpisah. Ketika perceraian telah disahkan oleh pengadilan, hal tentang anak pun juga menjadi pertimbangan. Lalu munculah hak asuh anak. Hak asuh anak seringkali menjadi pemicu pertikaian pada pasangan. Orang tua memiliki kewajiban mengasuh dan membesarkan anaknya, hal ini dijelaskan dalam Pasal 7 Ayat (1) Undang-Undang No. 23 Tahun 2003 tentang

\footnotetext{
${ }^{25}$ Lihat Undang-Undang Republik Indonesia No. 1 Tahun 1974 tentang Perkawinan.

${ }^{26}$ Lihat Undang-Undang Republik Indonesia No. 13 Tahun 2003 tentang Ketenagakerjaan.

${ }^{27}$ Lihat Undang-Undang Republik Indonesia No. 11 Tahun 2012 tentang Sistem Peradilan Anak.

${ }^{28}$ Lihat Undang-Undang Republik Indonesia No. 23 Tahun 2002 tentang Perlindungan Anak.
} 
Perlindungan Anak, Pasal 45 Ayat (1) dan (2) Undang-Undang No. 1 Tahun 1974 tentang Perkawinan. Setiap anak berhak mendapat kehidupan yang layak, pendidikan, kebebasan, aman dari ancaman kekerasan dan diskriminasi, dan lain sebagainya sebagaimana dijelaskan dalam Pasal 4 Undang-Undang No. 23 Tahun 2002 tentang Perlindungan Anak. Pasal 105 Kompilasi Hukum Islam (KHI) menyebutkan bahwa anak di bawah umur 12 tahun diasuh oleh ibunya, dan anak di atas umur 12 tahun berhak memilih pemegang hak asuh di antara ayah atau ibunya. Untuk biaya penghidupan anak ditanggung oleh ayah. Ketika kondisi ayah tidak memungkinkan atau tidak bisa memenuhi kewajiban tersebut, ibu berhak ikut andil untuk menanggung biaya penghidupan anaknya. Bagi salah satu orang tua yang mengambil anak di bawah umur secara paksa tanpa izin dari pemegang hak asuh utama, dapat dikenakan Pasal 330 KUHP dan diancam pidana penjara paling lama 7 (tujuh) tahun, apabila terdapat kekerasan atau ancaman kekerasan dan sebagainya, diancam dengan pidana penjara paling lama 9 (sembilan) tahun. R. Soesilo mengatakan jika memang pelaku yang menarik/mengambil anak tersebut dari pemegang hak asuh, harus dapat dibuktikan. Ditegaskan dalan arrest Hoge Raad 2 November 1903 apabila anak memang melepaskan diri dari pemegang hak asuh yang sah dengan dasar kemauan diri sendiri dan meminta pertolongan kepada seorang yang lain, serta menolak untuk mengembalikannya kepada pemegang hak asuh anak yang sah, maka penolakannya ini tidak dapat dikatan sebagai menarik seorang dibawah umur dari kekuasaan pemegang hak asuh anak tersebut. Perundang-undangan di Indonesia juga mengatur mengenai batasan umur anak. Yang dimaksud anak di bawah umur dalam Pasal 330 KUHP mengacu pada Pasal 1 Ayat (1) Undang-Undang No. 23 Tahun 2002 tentang Perlindungan anak, yakni berumur 18 (delapan belas) tahun.

\section{DAFTAR PUSTAKA}

\section{Buku}

Abdul Rahman Ghozali. (2003). Fiqh Munakahat. Jakarta: Prenada Media Group.

Ahmad Azhar Basyir. (2000). Hukum Perkawinan Islam. Yogyakarta: UI Pres.

Arif Gosita. (1998). Masalah Perlindungan Anak. Jakarta: Akademika Pressindo.

Johnny Ibrahim. (2013). Teori dan Metodologi Penelitian Hukum Normatif. Malang: Bayumedia.

P. N. H. Simanjutak. (2007). Pokok-Pokok Hukum Perdata Indonesia. Jakarta: Pusaka Djambatan.

Sorejono Soekanto \& Sri Mamudji. (2001). Penelitian Hukum Normatif ( Suatu

Tinjauan Singkat). Jakarta: Rajawali Pers.

Subekti. (1985). Pokok-Pokok Hukum Perdata. Jakarata: Intermasa.

\section{Perundang-undangan}

Kitab Undang-Undang Hukum Pidana (KUHP)

KUHPerdata

Undang-Undang Republik Indonesia Nomor 1 Tahun 1974 Tentang Perkawinan dan

Undang-Undang Republik Indonesia No. 23 Tahun 2002 tentang Perlindungan Anak.

Undang-Undang Republik Indonesia No. 13 Tahun 2003 tentang Ketenagakerjaan.

Undang-Undang Republik Indonesia No. 11 Tahun 2012 tentang Sistem Peradilan Pidana 
Anak.

Kompilasi Hukum Islam (KHI).

Peraturan Pemerintah No. 9 Tahun 1975 tentang Pelaksanaan Undang-Undang No. 1 Tahun 1974 tentang Perkawinan.

Artikel, internet, dll

Fitri N Hariani, 2018,Perkawinan Retak, Hak Asuh Anak Diperebutkan, diakses pada 12 April 2020dari https://www.hukumonline.com/berita/baca/lt5b1 fa3dce96d9/ perkawinan-retak--hak- asuh-anak-diperebutkan/

Steven Lie, S.H. 2019. Cara Mengajukan Gugatan Nafkah Anak ke Pengadilan Negeri diakses pada 20 April 2020 dari https:/www.hukumonline.com/klinik/detail/ ulasan/lt5680f6d47502d/cara-mengajukan-gugatan-nafkah-anak-ke-pengadilannegeri/

Sovia Hasanah, 2019, Melaporkan Pidana Mertua yang Melarang Menemui Anak Sendiridiakses pada 28 April 2020 dari https://www.hukumonline.com/klinik/detail/ ulasan/lt5169407db97ce/melaporkan-pidana-mertua-yang-melarang-menemui-anaksendiri/ 